The origins and development of African livestock

\section{Archaeology, genetics, linguistics and ethnography}

Edited by Roger M. Blench and

Kevin C. MacDonald

and

29 West 35th Street

New York, NY 10001

USA

The name of University College London (UCL) is a registered trade mark used by UCL Press with the consent of the owner.

UCL Press is an imprint of the Taylor \& Francis Group

(C) Roger Blench, Kevin MacDonald and contributors, 2000

All rights reserved. No part of this book may be reprinted or reproduced or utilised in an form or by any electronic, mechanical, or other means, now known or hereafter invented including photocopying and recording, or in any information storage or retrieval system. without permission in writing from the publishers.

British Library Cataloguing in Publication Data

A catalogue record for this book is available from the British Library

Library of Congress Cataloging in Publication Data A catalogue record for this book has been requested

ISBN 1-84142-018-2 HB 


\title{
Domestic animals from archaeological sites in Central and west-central Africa
}

\author{
Wim Van Neer
}

\section{Introduction}

Information on the presence and propagation of domestic animals in Central Africa is scanty. This is a combined result of the few excavations carried out thus far, and the poor chances for preservation of bone in this region. The acidity of the soils, particularly in forested regions, is responsible for the low survival chances of saunal remains. The paucity of sites with fauna is clearly illustrated on Figure 9.1 which indicates both Iron Age and Stone Age sites in the region under consideration. Archaeozoological material occurs mainly in open air sites of very recent date and in caves or rock shelters. The only sites in the equatorial rainforest where and in caves or hack thus far been found are Matupi cave and the seventeenth to faunal remains have thus far been found are Matupi cave and sites such as Dimba, nineteenth century AD open air site of Nkile. Other cave sites such (the forestNgovo and Ntadi Yomba lie presently in a heavily wooded environment (the forestsavanna mosaic). In the Grassfields of Cameroon, faunal remains were also found in a series of caves. Rapid, and by prefer air sites. Alluvial and lacustrine deposits make good preservation possible in open air sites. Alluvial and is the case of certain can, therefore, sometimes yield abundant faunal remains. This is the case of certain sites found in the lshango region where lake dep57, Hopwood \& Misonne 1959). sequence studied in the 1950s (de Heinzelin 1957, Hopwo in the alluvial Semliki Research was resumed in the late 1980s north of Ishango in the alluvial Semliki Beds, and also yielded sites with good faunal preservation (Brooks \& Smith 1987 , Peters 1990, Brooks et al. 1995). Another type of deposit where Upemba Depresditions can be favourable are human burials such as found associated with human sion region of Zaire where animal remains were found associated with human skeletons. The filling of pits is another type of deposit where preservant at Nkang quite good when infilling is rapid. This is certainly true for the pits found at Nkang in Cameroon for instance. Finally, there are some faunal assemblages wheat by the well-preserved in she case for Oveng in Gabon and several sites in Angola. 


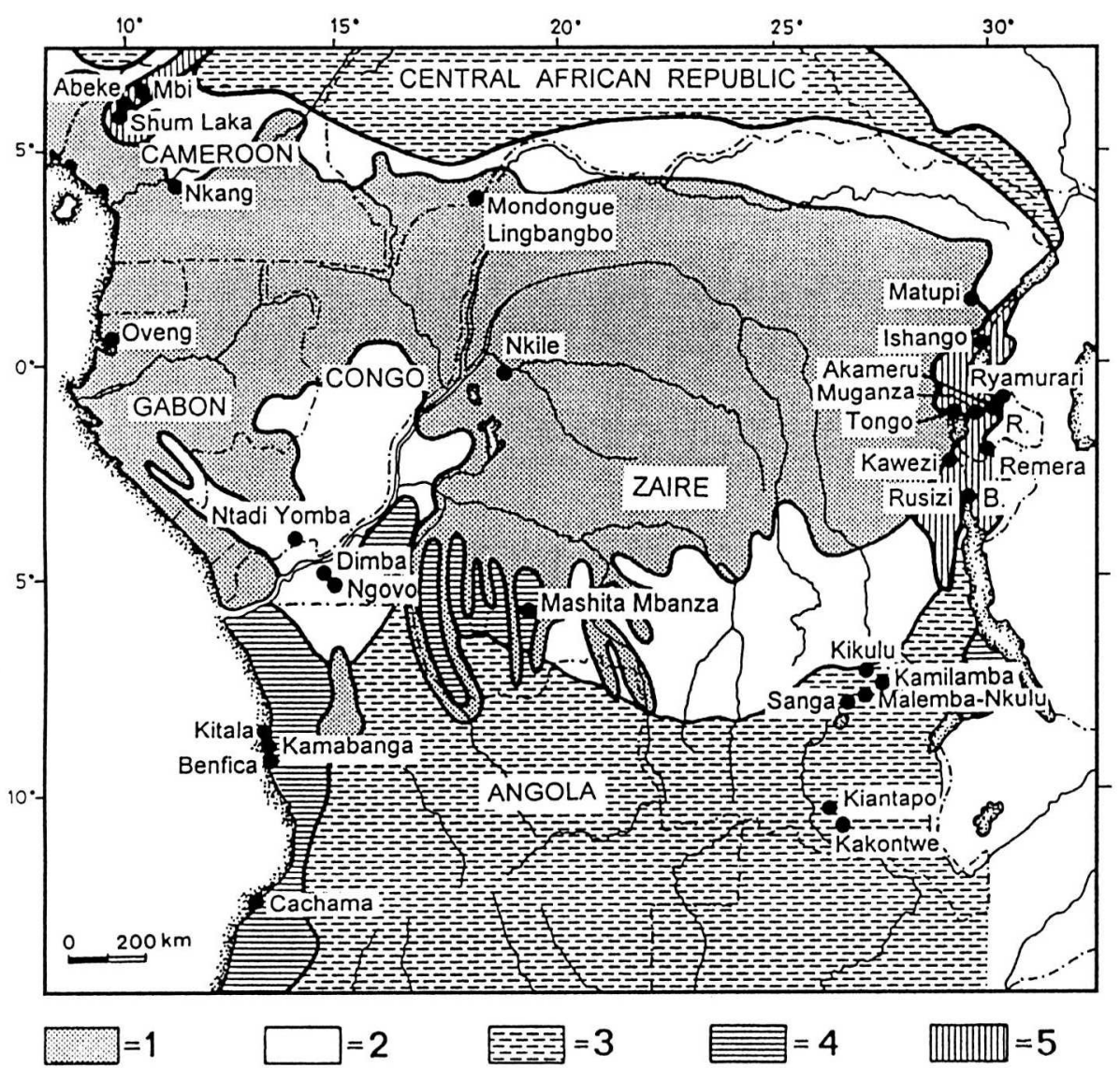

Figure 9.1 Map showing Central African Stone Age and Iron Age sites with faunal remains. The main vegetation belts are also indicated. 1 = evergreen forest; 2 = forest-savanna mosaic; $3=$ woodland savanna; $4=$ grass savanna; $5=$ montane habitats.

\section{Overview of sites}

The region considered in this overview comprises the area from about $5^{\circ} \mathrm{N}$ to $13^{\circ} \mathrm{S}$ and from the Atlantic coast to the interlacustrine region. Included are all sites with domestic animals as well as some additional settlements where such animals were lacking despite the relatively recent age of their deposits. Well-preserved bones allowing measurements occur only sporadically, with these data mostly given in the text. The measurements are in millimetres and have been taken according to von den Driesch (1976). Shoulder heights of domestic cattle, sheep and goat were calculated whenever complete long bones were available. The indices used are those summarized by von den Driesch \& Boessneck (1974). A regional overview of the
A list of radiometric dates from the sites with domestic animals is given in Table 9.9. This separate list indicates the laboratory dates as well as the corresponding calibrated minimum and maximum dates (One Sigma) calculated with the OxCal v2.15-programme. The calibrated values are used in the text.

\subsection{Cameroon}

2.1.1. Nkang The site of Nkang lies on the top of a hill that gradually slopes towards the Sanaga river. It belongs to the so-called Obobogo tradition, which refers to the earliest village communities in Cameroon, typically installed on hill tops near Yaoundé since the end of the second millennium BC. The precise extension of the Obobogo tradition still remains to be established but Nkang is the most southerly indication for it. The archaeological material from these sites derives mainly from large pit structures and comprises, in general, pottery, grinding stones, polished stone axes, metal slag, and remains of Elaeis guineensis and Canarium schweinfurthii. The latter finds have sometimes been interpreted as a possible indication for some form of agriculture (de Maret 1991:45), but indications for animal husbandry was at that time lacking from sites of the Obobogo tradition. This is owing to the fact that faunal remains were poorly preserved, if at all, in previous excavations. Obobogo is the only open air site in southern Cameroon, besides Nkang, to have yielded fauna. The only preserved bone fragment at Obobogo is from a brush-tailed porcupine Atherurus africanus (de Maret 1991:45) and was found in a pit dated to the end of the first millennium BC. The archaeological material comprises iron slag and ceramics of the beginning of the early Iron Age. One potsherd showed an impression of a Pennisetum grain (Claes 1985).

The site of Nkang comprises a number of refuse pits distributed over an area of about one hectare. Thirteen of these pits were excavated in 1990 (Mbida 1996) and yielded pottery, a polished stone axe fragment and other lithic material, iron slag, burnt remains of Canarium and Elaeis, and a total of about 100 bone fragments. Radiocarbon dates indicate that Nkang was inhabited between the eighth and second centuries BC. Table 9.1 gives an overview of the animals identified (Van Neer, unpubl. data). The majority of the fauna represents human food waste, with only a few remains being considered as intrusive elements. This is the case for the Limicolaria shells and for the small rodents. The former typically colonize human habitation areas and may be more or less contemporaneous with the occupation phase. The small rodents, on the other hand, are less fossilized than the rest of the faunal material indicating that they represent animals that burrowed and died in the archaeological layers at a more recent date.

The fauna discovered at Nkang allows a reconstruction of the former environment. The Achatina shells, the bushbuck, the forest duikers and the forest buffalo indicate a rather dense forest, whereas the waterbuck and kob are typical of more open habitats. The former environment may thus have resembled the modern one, i.e. a forest-savanna mosaic.

The subsistence of the inhabitants of Nkang relied, as far as animals are concerned, on the collecting of molluscs, fishing, hunting and animal husbandry. Both 


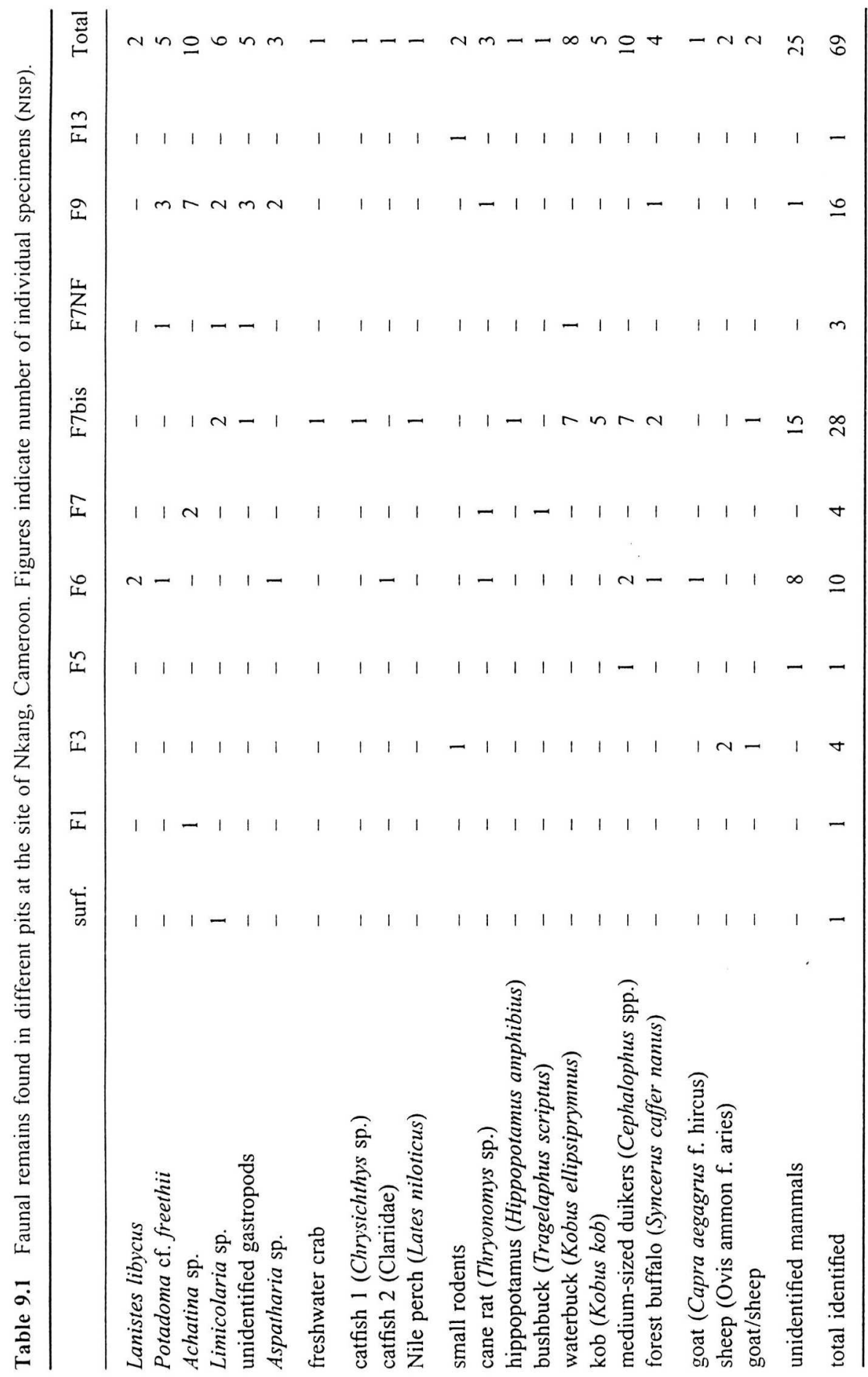

as well as freshwater crabs, were probably taken from the nearby tributary of the Sanaga river. Fishing may have played an important role as well and relied on various techniques judging from the habitat preferences of the species. Various parts of the river were exploited. The fish captured comprise animals typical of open, deep water (Lates niloticus), bottom-dwellers (Chrysichthys and Clariidae), as well as small schooling fish occurring inshore near the surface (Alestes/Brycinus). Remains of the latter group of fish, as well as some small cyprinids were found in a sieve sample not included in Table 9.1. Hunting concentrated mainly on antelopes of medium to large size but included the forest buffalo and smaller animals such as the cane rat. The wide variety of exploited animals illustrated by only a small faunal sample may be considered as typical of relatively sedentary communities cf. Flannery 1972, Tchernov 1993). The presence of small stock is attested to by five bones only. They were found in the following pit structures: F3 dated between $760 \mathrm{BC}$ and $400 \mathrm{BC}, \mathrm{F} 6$ dated between $830 \mathrm{BC}$ and $540 \mathrm{BC}$, and F7bis dated to $760-260 \mathrm{BC}$. A goat humerus with its proximal end unfused was found in F6 and had the following dimensions: Bd $24.2 \mathrm{~mm}$; BT $23.2 \mathrm{~mm}$. These measurements, as well as the overall size of the bone, indicate a rather small breed, comparable in size to the dwarf goats found in equatorial Africa today (Epstein 1971:211). The presence of sheep is attested in pit F3 by a distal fragment of a metatarsal belonging to a sub-adult specimen and by a complete third phalanx (DLS $21.6 \mathrm{~mm}$; Ld $18.0 \mathrm{~mm}$ ). Both specimens belong to a small breed comparable to the dwarf breed of thin-tailed hair sheep that is widely distributed today in the tropical forest of Africa (Epstein 1971:48). This is the oldest evidence for ovicaprines in Central Africa.

2.1.2. Cave sites The excavation since the 1980s of a number of caves and rock shelters in the Grassfields has yielded large faunal assemblages. The initial purpose of the research conducted in this area was to document the period of transition between the Late Stone Age and the Metal Ages and studying the possible relationship with the first stages of Bantu expansion (de Maret 1980). Major faunal assemblages are available from the sites of Abeke, Mbi Crater and Shum Laka I and II.

Abeke, explored in 1980 by Pierre de Maret, yielded a Late Stone Age industry in layers dated to the fifth millennium BC. The overlying surface layers contained a few pottery sherds but have not been dated. These upper levels yielded the same forest fauna as the deeper ones; there is no evidence for domestic species at all (de Maret et al. 1987).

Excavations at Mbi Crater yielded a Late Stone Age industry in two phases. A shift is seen through time from a savanna fauna, in the earliest phase dated between about $25,000 \mathrm{bp}$ and $18,000 \mathrm{bp}$, to an assemblage typical of a more densely wooded vegetation, from about $9000 \mathrm{bp}$ onwards. The earliest occurrence of pottery is seen in a level dated to 3050-2500 BC; the upper layer is dated to 1090-810 BC (Warnier \& Asombang 1982, Asombang 1988). Some Canarium schweinfurthii and Elaeis guineensis were found but domestic animals are lacking throughout (Asombang 1988). 
The site of Shum Laka I has yielded thousands of faunal remains. A test excavation was carried out in 1980 (de Maret et al. 1987) and extensive excavations followed in the 1990s (Asombang \& de Maret 1992, de Maret et al. 1993, 1995 Cornelissen et al. 1995). A detailed stratigraphic sequence of $3 \mathrm{~m}$ is now available. Iron Age pottery was found in the upper grey ash layers dated from the fourth century $\mathrm{BC}$ to the thirteenth century $\mathrm{AD}$, with dates for the deeper layers ranging between $6000 \mathrm{bp}$ and $30,000 \mathrm{bp}$. I have analyzed material from all of these layers, but was unable to see any shifts in the fauna through time. Only forest animals occur throughout the sequence, although botanical analyses (pollen, phytoliths and charcoal) have only yielded evidence for savanna species. This seems to suggest that Shum Laka cave was situated at the fringe of the savanna and forest. The giant forest hog (Hylochoerus meinertzhageni) and forest buffalo (Syncerus caffer nanus) predominate in all levels, whereas cercopithecids and duiker antelopes are also very common. No savanna animals appear in the younger levels and there is no trace of domestic animals either. A similar situation was found at the smaller Shum Laka II, a nearby rockshelter with shallower archaeological deposits.

\subsection{Central African Republic}

Mondongue and Lingbangbo are two open air sites in the tropical forest south of Bangui. They yielded fauna, pottery, metal slag, metal objects and few lithic remains (Koté 1992). Radiometric dates place the occupation of Mondongué between the sixteenth and twentieth centuries AD, whereas Lingbangbo was inhabited some time between the fourteenth and seventeenth centuries AD. The present-day inhabitants of the area keep chickens, goats and dogs. The fauna from the site comprises mainly wild animals but domestic species occur in small numbers (Table 9.2). Seven fragments of ovicaprines were found at Lingbangbo but it was impossible to identify these to a species level. However, a distal humerus (BT $26.5 \mathrm{~mm}$ ) found at the site of Mondongue could be definitely identified as goat. The dimensions of this piece indicate a small breed. Domestic dog is represented by at least six remains of a medium-sized breed at Lingbangbo and may also have been present at Mondongué. The shoulder height of the dogs from Lingbangbo is estimated at about $45 \mathrm{~cm}$ on the basis of direct comparison of a distal humerus $(\mathrm{Bd} 23.0 \mathrm{~mm})$ with modern skeletons.

\subsection{Gabon}

2.3.1. Oveng This site is a shell midden at $12 \mathrm{~km}$ northeast of Libreville. It consists of a $30 \mathrm{~m}$ high hilltop surrounded by mangroves and equatorial forest. A small tributary of the Bombie river, running to the Mondah bay, lies close to the site. Excavations yielded pottery, iron slag, faunal remains, carbonized nuts of Elaeis guineensis and Coula edulis, and charcoal (Clist 1987, 1989). Analysis of the archaeological material and the stratigraphy shows that this is a single-component site dated between the first century AD and the sixth century AD. The shells comprise Anadara senilis (78 per cent), Tympanotus fuscus and T. radula (13.5 per cent), Ostrea tulipa (5 per cent), and Semifusus morio (3.5 per cent) (Van Neer \& Clist 1991). About 3,000 vertebrate remains were found of which only a small portion
Table 9.2 Faunal remains from the sites of Mondongue and Lingbango, Central African Republic. Figures indicate number of individual specimens (NISP).

\begin{tabular}{|c|c|c|c|c|c|c|c|}
\hline & \multicolumn{5}{|c|}{ LINGBANGBO } & \multicolumn{2}{|c|}{ MONDONGUE } \\
\hline & \multicolumn{5}{|c|}{ main test trench } & \multirow{2}{*}{\multicolumn{2}{|c|}{ layer }} \\
\hline & \multirow{2}{*}{$\frac{\text { layer }}{1}$} & \multicolumn{4}{|c|}{ layer } & & \\
\hline & & 1 & 3 & 5 & 6 & 1 & 2 \\
\hline Achatina sp. & - & - & - & - & - & - & 1 \\
\hline Polypterus sp. & - & - & - & 3 & - & - & - \\
\hline Mormyridae indet. & - & - & - & 1 & - & - & - \\
\hline Cyprinidae indet. & - & - & - & 1 & - & - & - \\
\hline catfish 1 (Clariidae) & - & - & - & 10 & - & - & - \\
\hline catfish 2 (Auchenoglanis sp.) & - & - & - & 1 & - & - & - \\
\hline unidentified catfish & 1 & - & - & 10 & - & - & - \\
\hline Parachanna sp. & 1 & - & - & 3 & - & - & - \\
\hline unidentified perciform & - & - & - & 1 & - & - & - \\
\hline Kinixys sp. & 1 & - & - & - & - & - & - \\
\hline Pelomedusidae & - & - & - & 2 & 1 & - & - \\
\hline Cyclanorbis sp. & - & - & - & 1 & - & - & - \\
\hline Python sp. & - & - & - & 2 & - & - & - \\
\hline Crocodylidae & - & - & - & 2 & - & - & - \\
\hline guenon (Cercopithecus sp.) & 1 & - & - & - & - & - & - \\
\hline Cercopithecidae & - & - & - & - & - & - & 1 \\
\hline giant rat (Cricetomys sp.) & - & - & - & 6 & - & - & - \\
\hline porcupine (Atherurus africanus) & - & - & - & - & - & - & 1 \\
\hline elephant (Loxodonta africana) & - & - & 1 & - & - & - & - \\
\hline bushpig (Potamochoerus porcus) & 5 & - & 1 & 2 & 1 & - & 2 \\
\hline blue duiker (Cephalophus monticola) & - & - & - & 9 & 5 & - & - \\
\hline medium-sized duikers (Cephalophus spp.) & 7 & 2 & - & 9 & 2 & 1 & - \\
\hline sitatunga (Tragelaphus spekei) & - & - & - & - & - & 1 & 1 \\
\hline waterbuck (Kobus ellipsiprymnus) & - & - & - & - & - & - & 1 \\
\hline African buffalo (Syncerus caffer) & - & - & - & 1 & - & - & - \\
\hline $\operatorname{dog}$ (Canis lupus f. familiaris) & 1 & - & - & 4 & 1 & - & $1 ?$ \\
\hline goat (Capra aegagrus f. hircus) & - & - & - & - & - & - & 1 \\
\hline goat/sheep & - & - & - & 7 & - & - & - \\
\hline unidentified mammals & 15 & 2 & 4 & 25 & 7 & 10 & 8 \\
\hline total identified & 17 & 2 & 2 & 75 & 10 & 5 & 11 \\
\hline
\end{tabular}


was identifiable owing to the extreme fragmentation. More than 97 per cent of the complete bone collection belongs to fish. The species present, and their small reconstructed size, indicate that fishing was practised in the mangrove rivers near the site. Mammal bones were heavily under-represented. The only identifiable mammalian remains were from small, intrusive rodents. The remaining mammal bone fragments were unidentifiable but belonged to medium-sized animals (size of duiker antelope or ovicaprines). The faunal data hence indicate that the inhabitants of Oveng relied mainly on shell-collecting and fishing.

\subsection{Congo (Zaïre)}

2.4.1. Matupi This cave, which is situated in the rainforest at about $70 \mathrm{~km}$ west of Lake Mobutu, yielded a microlithic LSA industry dated between about $3000 \mathrm{BP}$ and more than 40,000 BP (Van Noten 1977). The upper layers comprise Iron Age material and have been dated to the thirteenth and fourteenth centuries AD. The only possible indication for domestic animals is a lower second premolar of a canid found in the Iron Age levels (Van Neer 1989). It was, however, impossible to identify this piece with certainty as domestic dog. The tooth is also very similar to the corresponding one from jackals (Canis adustus and Canis mesomelas) living in the region.

2.4.2. Ngovo and Dimba The excavation of these two caves, and six other sites, in Lower Zaire was aimed at detailing the archaeological context of polished stone tools frequently found at the surface in the savannas just south of the equatorial forest. These polished stone tools are systematically found in association with pottery of the so-called "Group VI" which de Maret (1986) proposed to designate as the "Ngovo Group". The industry is placed within the last few centuries BC by a series of dates in good agreement. The Ngovo Group has been considered by several authors as possible evidence for the colonization of this part of the continent by Bantu-speaking farmers. The systematic absence of metal in the Ngovo Group sites seems to indicate that it was pre-metallurgical. It is only in the second century $\mathrm{AD}$ that the first iron appears in the region. A fragment of a Canarium schweinfurthii nut was found at Ngovo which de Maret (1986) considers as a possible indication of a form of agriculture or arboriculture. No domestic animals occur among the faunal assemblages from Ngovo (Van Neer 1986) and Dimba (Van Neer 1990). The samples are both very small and comprise only 38 and 98 identifiable fragments, respectively. The faunal remains are all from wild animals, with in both cases a clear preponderance of species typical of closed environments. The fauna seems to indicate that the immediate surroundings of both sites were more heavily wooded than they are today, a hypothesis that is also supported by botanical evidence for Ngovo (Deschamps 1986).

2.4.3. Kawezi Kawezi is an open air site in the Ruzizi valley that has yielded early Iron Age pottery, charcoal and animal bones (Maquet \& Hiernaux 1969). No radiometric dates are available. The pottery differs from the types usually encountered in the region and resembles most closely the channelled ware of Zambia. The terrestrial fauna has been partially identified by S. Frechkop (Brussels) and comprises the remains of hyena, buffalo, a reduncine antelope (Kobus ellipsiprymnus?), Tragelaphus, and some antelopes of larger size (eland antelope?). No domestic animals have been reported but it would be interesting to re-investigate this material, especially the specimens identified as buffalo. Using Peters' (1988) diagnostic criteria for separating the post-cranial elements of buffalo and domestic cattle it should be possible to see if domestic cattle were present at Kawezi.

2.4.4. Upemba Extensive fieldwork has been carried out in a series of Iron Age necropolises in the Upemba Depression (de Maret 1985a). The excavations took place in four areas: Kamilamba and Kikulu at the shore of Lake Kabamba, Malemba Nkulu at the right bank of the Lualaba, and Sanga along Lake Kisale. A chronological framework has been established for the human occupation in the region on the basis of more than 40 radiocarbon dates (not mentioned in Table 9.9; see de Maret 1982, Geyh \& de Maret 1982). The Kamilambian phase starts in the sixth century AD and is replaced by the Ancient Kisalian during the eighth century. The Classic Kisalian starts around the tenth century and is followed by the Kabambian $\mathrm{A}$ in the thirteenth to fourteenth centuries. The latter is replaced by the Kabambian $B$ in the sixteenth century and lasts until the eighteenth century.

The faunal remains were found in close association with the human skeletons or in the pottery that accompanied them (Van Neer 1990). Except for some intrusive rodent skeletons, all the faunal remains are considered as funerary gifts. Fish bones are dominant throughout the sequence and only at Sanga were substantial numbers of other vertebrates (mammals and birds) found. The graves from Sanga belong to the Classic Kisalian and date between the tenth and thirteenth/fourteenth centuries. They yielded a large number of metapodials from bovids. One of them was a goat metacarpal of which the distal ends were fusing. This specimen has the following dimensions: GL $89.0 \mathrm{~mm}$; Bp $21.1 \mathrm{~mm}$; SD $14.4 \mathrm{~mm}$; Bd $25.4 \mathrm{~mm}$. The corresponding shoulder height of this animal was about $51 \mathrm{~cm}$, which is more or less the upper limit for dwarf breeds (Epstein 1971:211). Another grave from Sanga yielded a complete skeleton of a galliform bird identified as a domestic chicken.

24.5. Mashita Mbanza Mashita Mbanza is situated at about $50 \mathrm{~km}$ southeast of Kikwit in a grassland environment. The site comprises a series of about ten small mounds in a semicircle. The genesis and the function of these mounds is unclear. They contain earth, charcoal, metal slag, pottery, metal objects, kitchen debris and, in some cases, cattle dung. Oral traditions of the Pende refer to Mashita Mbanza as the area where they lived before migrating to their present-day homeland. The site was discovered by Maes (1935) and re-excavated by de Maret in 1984. Radiocarbon dates place the occupation between the sixteenth and twentieth centuries AD (Pierot 1987). About 100 mammal remains have been found of which only 16 were identifiable (Van Neer 1990). They comprise hunted animals as well as domestic species Wild mammals identified from this site are cane rat (Thryonomys swinderianus), banded mongoose (Mungos mungo), warthog (Phacochoerus aethiopicus) and bush duiker (Sylvicapra grimmia). The latter two species indicate that the environment 
was also open at the time of the occupation. Three bones of ovicaprines were found, one of which is identifiable as sheep. Firm osteological evidence for cattle is not available. There is one incisor of a large bovid which cannot be attributed with certainty to either domestic cattle or African buffalo. The excavators reported, however, that cattle dung was present in some of the mounds.

2.4.6. Nkile An extensive archaeological survey carried out along the main rivers of the equatorial forest in Zaire (Eggert 1983, 1984, 1987) showed that faunal preservation is very poor in this area. Animal remains were only discovered at Nkile, a village situated along the Ruki river at about $3 \mathrm{~km}$ downstream Bokuma. Most of the faunal remains are from levels belonging to the Botendo horizon. The corresponding occupation covers the nineteenth century but might go back to the eighteenth or seventeenth centuries (Eggert pers.comm.). The fauna comprises molluscs, most of which are probably intrusive, as well as fish and mammal bones representing food remains (Table 9.3). Although the assemblage is small, it seems that the inhabitants relied mainly on fishing. Animal husbandry and hunting were apparently practised to a lesser degree. The wild mammals indicate a densely wooded environment (guenon Cercopithecus sp. and blue duiker Cephalophus monticola). Domestic animals comprise pig, ovicaprines and dog. The lower jaw of a suid could be assigned to domestic pig on the basis of the dental characters distinguishing Sus scrofa from Potamochoerus porcus (Cooke \& Wilkinson 1978). Ovicaprines are represented by a molar and a fragment of a first phalanx. An ulna of a domestic dog shows cutmarks.

2.4.7. Kiantapo Kiantapo cave, situated on the western slope of the Biano plateau in Shaba, is famous for its rock engravings (Breuil 1952, Mortelmans 1952). Excavations carried out in front of the cave by Cabu (1938) and in 1955 by Mortelmans have not allowed a precise dating of the engravings. The archaeological material of the 1955 fieldwork belongs mainly to the late Iron Age and is not more than two centuries old (Mortelmans \& de Maret 1989). The pottery is of the type still locally produced by the Bena Mitumba. Oral traditions stipulate that the Bena Mitumba are Luba coming from the region of Kanda Kanda. After they settled in the Biano area, conflicts occurred with other Luba groups and with Msiri people. It is likely that the Kiantapo cave, and many other caves in the area, had been used as a refuge during these periods of instability. The numerous faunal remains found in Kiantapo cave indicate that the inhabitants relied almost exclusively on hunting (Van Neer 1989). This was practised both on the grassy plains on top of the Biano plateau, and on its wooded slopes. The only domestic animal that was found is chicken. The absence of other domestic species is surprising for a site of such a recent date. This may be related to the fact that the deposits were formed by people seeking refuge in periods of insecurity. They may have been able to only bring along the smallest domestic stock they had.

2.4.8. Tongo This site, which lies at about $50 \mathrm{~km}$ north of Lake Kivu, was discovered during road construction works between Masisi and Rutshuru. The
Table 9.3 Faunal remains from the site of Nkile, Zaïre. Figures indicate number of individual specimens (NISP).

\begin{tabular}{lc}
\hline & NISP \\
\hline Homorus sp. & 2 \\
Limicolaria sp. & 1 \\
Subulina cf. avakubiensis & 1 \\
unidentified gastropods & 2 \\
Protopterus sp. & 1 \\
Polypterussp. & 8 \\
Mormyrops sp. & 5 \\
Cyprinidae & 1 \\
Clariidae & 20 \\
Synodontis sp. & 3 \\
Bagridae & 4 \\
Tilapiini & 7 \\
Ctenopoma sp. & 1 \\
Parachanna sp. & 49 \\
unidentified fish & 80 \\
crocodile & 2 \\
Cercopithecidae & 1 \\
Genetta sp. & 1 \\
Cephalophus monticola & 2 \\
Cephalophus sp. & 3 \\
small bovid & 2 \\
pig & 1 \\
sheep/goat & 2 \\
dog & 1 \\
unidentified mammals & 22 \\
\hline
\end{tabular}

vegetation in the area is mainly grassland with patches of forest. Because of its high elevation the region is free of trypanosomiasis which renders it very suitable for herding. Excavations yielded pottery with twisted cord roulette decoration and sherds of the Urewe tradition. Aside from the surface layers, three main entities have been distinguished (Kanimba pers. comm.): the levels between $70 \mathrm{~cm}$ and $150 \mathrm{~cm}$ comprise roulette-decorated pottery; between $150 \mathrm{~cm}$ and $210 \mathrm{~cm}$ Urewe pottery was found, whereas the levels between $210 \mathrm{~cm}$ and $300 \mathrm{~cm}$ yielded a mixture of Urewe pottery and finely decorated sherds with a polished surface. Associated with the Urewe pottery were also worked shells, some iron objects and iron slag (Kanimba \& Gatare 1992). Radiocarbon dates place the Urewe occupation between the third and sixth centuries AD. Human skeletons were found as well, but their age is uncertain. Faunal remains occur throughout the sequence (Table 9.4). Domestic cattle and ovicaprines are present in all levels and make up about 40 per cent of the total 
Table 9.4 Faunal remains from the different levels at the site of Tongo, Zaïre. Figures indicate number of individual specimens (NISP).

\begin{tabular}{|c|c|c|c|c|c|}
\hline & \multicolumn{2}{|c|}{ Late Iron $A g e$} & \multicolumn{2}{|c|}{ Early Iron Age } & \multirow{2}{*}{ total } \\
\hline & surface & $70-150 \mathrm{~cm}$ & $150-210 \mathrm{~cm}$ & $210-300 \mathrm{~cm}$ & \\
\hline Achatina sp. & - & 1 & - & - & 1 \\
\hline large Gastropoda & 1 & - & 3 & 1 & 5 \\
\hline Clariidae & 1 & 1 & - & 4 & 6 \\
\hline Bagrus sp. & - & - & 1 & 1 & 2 \\
\hline Tilapiini & - & 20 & 14 & 5 & 39 \\
\hline fish identified & 1 & 21 & 15 & 10 & 47 \\
\hline fish indet. & - & 14 & 3 & 1 & 18 \\
\hline Francolinus sp. & - & - & 1 & - & 1 \\
\hline Galliformes indet. & - & 1 & 1 & - & 2 \\
\hline bird identified & - & 1 & 2 & - & 3 \\
\hline bird indet. & - & 3 & 2 & - & 5 \\
\hline small rodents & - & 4 & 8 & 6 & 18 \\
\hline giant rat (Cricetomys sp.) & 1 & 5 & 4 & 3 & 13 \\
\hline baboon (Papio anubis) & - & - & - & 1 & 1 \\
\hline colobus monkey (Colobus sp.) & - & - & - & 1 & 1 \\
\hline cercopithecids (Cercopithecidae) & - & - & 2 & 2 & 4 \\
\hline serval (Felis serval) & - & - & - & 1 & 1 \\
\hline small carnivores & - & 2 & 2 & - & 4 \\
\hline hyrax (Procaviidac) & - & 1 & - & - & 1 \\
\hline elephant (Loxodonta afiricana) & - & 1 & - & - & 1 \\
\hline $\begin{array}{l}\text { giant forest hog (Hylochoerus } \\
\text { meinertzhageni) }\end{array}$ & 1 & 2 & 2 & 3 & 8 \\
\hline cattle (Bos primigenius f. taurus) & 6 & 16 & 7 & 5 & 34 \\
\hline sheep (Ovis ammon f. aries) & - & - & 1 & - & 1 \\
\hline goat (Capra aegagrus f. hircus) & 1 & 2 & 1 & 2 & 6 \\
\hline sheep/goat & 6 & 17 & 8 & 9 & 40 \\
\hline duiker (Cephalophus sp.) & - & 1 & 1 & - & 2 \\
\hline bushbuck (Tragelaphus scriptus) & 3 & 6 & 3 & - & 12 \\
\hline small bovid & 2 & 20 & 8 & 15 & 45 \\
\hline roan (Hippotragus equinus) & - & 1 & - & - & 1 \\
\hline mammal identified & 20 & 78 & 47 & 48 & 193 \\
\hline mammal indet. & 40 & 165 & 98 & 79 & 382 \\
\hline
\end{tabular}

number of identified specimens. Worth noting is that among the galliform remains no domestic fowl were recognized; only Francolinus could be identified. Fishing was concentrated on shallow water taxa (clariid catfish and tilapia). Hunting seems to have been practised to a greater extent in densely forested areas (giant forest hog, cercopithecids, duikers) than in more open habitats (baboon and roan).

Table 9.5 summarizes the most important measurements that could be taken on the sheep and goat bones. The complete ovicaprine metapodials allowed the
Table 9.5 Measurements of some selected ovicaprine bones from Tongo, Zaïrc. The remains come from the surface levels, late Iron Age, and early Iron Age deposits.

\begin{tabular}{|c|c|c|c|c|}
\hline \multirow[t]{6}{*}{ metacarpus } & & Larly Iron $\Lambda g c$ & & \\
\hline & & Ovis & & \\
\hline & GL & 96.3 & & \\
\hline & $\mathrm{Bp}$ & 19.1 & & \\
\hline & SD & 12.4 & & \\
\hline & $\mathrm{Bd}$ & 22.6 & & \\
\hline \multirow[t]{6}{*}{ metatarsus } & & Late Iron Age & Late Iron Age & surface \\
\hline & & Capra & Capra & Capra \\
\hline & GL & 97.2 & - & - \\
\hline & $\mathrm{Bp}$ & 17.2 & 17.7 & 18.0 \\
\hline & SD & 10.7 & - & - \\
\hline & $\mathrm{Bd}$ & - & - & - \\
\hline \multirow[t]{6}{*}{ phalanx 1} & & Early Iron Age & & \\
\hline & & Capra & & \\
\hline & Glpe & 32.3 & & \\
\hline & $\mathrm{Bp}$ & 11.6 & & \\
\hline & SD & 9.9 & & \\
\hline & $\mathrm{Bd}$ & 10.8 & & \\
\hline
\end{tabular}

calculation of shoulder heights for a sheep $(47 \mathrm{~cm})$ and for a goat $(52 \mathrm{~cm})$, showing that we are dealing with dwarf forms. No complete long bones of cattle were present for the calculation of height at withers but the available measurements suggest a medium to large-sized breed (Table 9.6).

\subsection{Rwanda}

2.5.1. Muganza I Fieldwork carried out in Rwanda and Burundi by Van Grunderbeek et al. $(1982,1983)$ concentrated on the early Iron Age period and aimed also at reconstructing the evolution of the former environment. Cores had been taken, among others, in the peat deposits along the western shore of Lake Ruhondo in northern Rwanda. Palynological analysis of sediments from Muganza I, dated between $400 \mathrm{BC}$ and $\mathrm{AD} 250$, revealed that wooded savanna with gallery forests existed near the site. Animal bones were found as well but there was no archaeological material associated with them. The rather complete state of preservation of the skeletal elements and the kind of deposit may indicate that the bones represent animals that have been trapped accidentally in the peat deposits. They may, therefore, be of a more recent date than the surrounding sediment dated to $2300 \mathrm{BP}$. An attempt to directly date the bones failed, however, owing to the poor collagen content. The faunal remains, which must be 2,300 years or younger, did not comprise any domestic species. Warthog Phacochoerus aethiopicus, a mediumsized antelope (size of bushbuck Tragelaphus scriptus), and African buffalo Syncerus caffer were the only animals recognized. The latter species is represented by a 
Table 9.6 Selected cattle measurements from various sites in the interlacustrine region Most of the data are from the literature (for references see description of sites), those from Tongo are new. Surface finds, late Iron Age and early Iron Age material from Tongo is indicated separately.

\begin{tabular}{|c|c|c|c|c|c|}
\hline scapula & BG & $\begin{array}{l}\text { Akameru } \\
\pm 43\end{array}$ & $\begin{array}{l}\text { Ryamurari } \\
\pm 48\end{array}$ & & \\
\hline \multirow[t]{2}{*}{ humerus } & & $\begin{array}{l}\text { Tongo } \\
\text { surf }\end{array}$ & late & & Akameru \\
\hline & BT & 61.5 & 68 & $\mathrm{Bd}$ & \pm 70 \\
\hline radius & $\mathrm{Bp}$ & $\begin{array}{l}\text { Tongo } \\
\text { early } \\
74\end{array}$ & & & \\
\hline \multirow[t]{2}{*}{ metatarsus } & & $\begin{array}{l}\text { Tongo } \\
\text { late }\end{array}$ & & Akameru & \\
\hline & $\mathrm{Bp}$ & 50.7 & & 48 & \\
\hline \multirow[t]{2}{*}{ phalanx 1} & & Akameru & Cyinkomane & & Ryamurari \\
\hline & GLpe & 63 & 65 & 66 & 65 \\
\hline \multirow[t]{5}{*}{ phalanx 1} & & $\begin{array}{l}\text { Gisagara } \\
\text { VII }\end{array}$ & Ruzizi & & \\
\hline & GLpe & 59.0 & 59.3 & 62.6 & 65.0 \\
\hline & $\mathrm{Bp}$ & 29.8 & 25.7 & 27.7 & 31.1 \\
\hline & SD & 24.0 & 21.8 & 21.3 & 26.2 \\
\hline & $\mathrm{Bd}$ & 28.6 & 24.4 & 26.9 & 31.1 \\
\hline \multirow[t]{5}{*}{ phalanx 2} & & $\begin{array}{l}\text { Tongo } \\
\text { early }\end{array}$ & Akameru & Ruzizi & \\
\hline & GLpe & 55.5 & 41.5 & 40.9 & \\
\hline & $\mathrm{Bp}$ & - & - & 27.8 & \\
\hline & $\mathrm{SD}$ & - & - & 20.7 & \\
\hline & $\mathrm{Bd}$ & 30.5 & - & 24.0 & \\
\hline
\end{tabular}

pelvis fragment and a distal tibia which could be discriminated from domestic cattle on the basis of the large size and the diagnostic morphological criteria established by Peters (1988).

2.5.2. Akameru and Cyinkomane These two caves are situated in the Musanza region a few kilometres west of Ruhengeri. Excavations, which were limited to a square metre test trench in each cave, yielded the same pottery throughout. It comprises mainly sherds with rouletted decoration, belonging to the late Iron Age (Van Noten 1983). Two radiocarbon dates place the corresponding occupation at Akameru between the ninth and thirteenth centuries AD. About 200 identifiable vertebrate remains were found (Gautier 1983a). Hunted animals comprise mainly antelopes (sitatunga Tragelaphus spekei and duiker Cephalophus nigrifrons) and large rodents (giant rat Cricetomys and cane rat Thryonomys). Domestic cattle, sheep, goat and chicken were found as well. They represent about 35 per cent of the consumed animals at Akameru, and 56 per cent at Cyinkomane. The measurements of a few post-cranial elements of domestic fowl indicate that it was a small race. Sheep predominate among the ovicaprines. The heavy fragmentation of the cattle remains and the absence of horn cores precluded any attempt of racial attribution. The measurements, however, would indicate a breed with a withers height between $105 \mathrm{~cm}$ and $130 \mathrm{~cm}$ (Gautier 1983a).

2.5.3. Remera I, Kabuye XIV and Gisagara These Iron Age sites lying in southern Rwanda have yielded faunal remains that have only been partially published. Excavations at Remera I yielded a furnace dated between AD 250 and AD 340. Associated with this structure were two cattle teeth identified by Gautier (Van Grunderbeek et al. 1983:41). They comprise a fragment of an upper molar, and a lower third molar of $34.8 \mathrm{~mm}$ long which was only slightly worn. This tooth was attributed to a young adult of which the shoulder height was estimated at $110 \mathrm{~cm}$. Similar cattle teeth were also found at the early Iron Age site Kabuye XIV in association with pottery. A somewhat larger assemblage of animal remains was found at Gisagara, $15 \mathrm{~km}$ east of Butare. This site comprises circular structures with roulette decorated pottery typical of the late Iron Age. Animal remains were found at Gisagara II, III, V and VII, showing that ovicaprines and cattle were kept. Twenty remains of cattle and one ovicaprine tooth were identified. A radiocarbon date for Gisagara II places the occupation in the eleventh to twelfth centuries AD. Comparison of the measurements (see also Table 9.6) with those from Manching would indicate a small breed of cattle with a shoulder height between $110 \mathrm{~cm}$ and $120 \mathrm{~cm}$ (Gautier, n.d.).

2.5.4. Ryamurari This proto-historic site is the capital of the ancient Ndorwa kingdom. It is situated at the top of the Mukana hill in northeast Rwanda. Two types of structure have been discovered near the flat hilltop. Circular-shaped, artificial depressions of 6-8 $\mathrm{m}$ diameter and 1-2.5 m deep occur, at the base of which sometimes granitic blocks were found. The large, flat stones bear cavities that fill with water during heavy rains. Cattle would have been watered here during the rainy season when the marshy riverbanks made access to the nearby rivers difficult. Small enclosures were found at the southwest of the hilltop which, according to oral traditions, were inhabited by the servants. The royal enclosures occur at the southeastern end of the settlement. They are much larger and are arranged around a great, central circular structure $48 \mathrm{~m}$ in diameter. The latter structure was surrounded by ramparts much higher than those of the other enclosures. The enclosures served for both stock-keeping and human habitation. The majority of the pottery found during the excavations was with rouletted decoration. Radiocarbon dates situate the beginning of the occupation in the mid seventeenth century. The site was inhabited until the early twentieth century (Tshilema Tshiluka 1983). The faunal remains collected during the first field season have been studied by Gautier (1983b). The royal enclosures yielded only three identifiable bones, all belonging to domestic cattle. In the servants' enclosures 20 cattle remains were found as well as 
three bones of hare. More than half of the cattle remains are from juvenile specimens. The proportion of juveniles may, in reality, have been much higher taking into account the relatively low probability of preservation for their bones. The remains of these young individuals probably represent male animals that were eliminated early from the herds. Meat from these young bulls and from older cows may have been of less importance in the economy of Ryamurare. It is likely that cattle were kept mainly for the production of milk as is still done today by Cushitic and Nilotic peoples. Additional faunal remains have been found during later excavations. The preliminary study of this material (Tshilema Tshiluka 1983) shows that ovicaprines were also kept. Some well-preserved horn cores of cattle indicate that they belonged to a race with long, lyrate horns.

\subsection{Burundi}

The only faunal remains known thus far from this country come from a mound in the Ruzizi plain (De Meulemeester \& Waleffe 1973). This site, which has not been named, yielded archaeological material comprising roulette decorated pottery, some pipe fragments, iron objects and glass beads. Radiocarbon dating places this late Iron Age assemblage between the seventeenth and twentieth centuries AD. The shape and the dimensions of the structure indicate an enclosure for livestock. Fauna is well-preserved as a result of the fast accumulation of cattle dung, kitchen refuse, and sand that was either transported by man or windblown. The vertebrate fauna is predominantly composed of fish (Van Neer 1990). The mammal remains comprise a few specimens of wild species (bushbuck Tragelaphus scriptus and zorilla Ictonyx striatus). The commensal black rat (Rattus rattus) is present as well. The majority of the identified mammal remains belong, however, to domestic cattle. A few measurable phalanges indicate animals of medium size (Table 9.6).

\subsection{Angola}

2.7.1. Kamabanga I and Kitala The excavation of Kamabanga, just south of Luanda, yielded a hearth in a layer of Anadara senilis shells. It dates to the ninth to tenth centuries AD (de Maret 1985b). Some sherds of finely decorated pottery and a few faunal remains were associated with the hearth. The bones comprise about ten fish remains, an astragalus of warthog (Phacochoerus aethiopicus), tibia fragments of Burchell's zebra (Equus burchelli) and a first phalanx of domestic cattle with the following measurements: Glpe $62.6 \mathrm{~mm}$; Bp $30.0 \mathrm{~mm}$; SD $25.8 \mathrm{~mm}$; Bd $28.6 \mathrm{~mm}$.

Kitala lies closely to the preceding site and has been dated to the thirteenth to fourteenth centuries AD (de Maret 1985b). The only faunal remains that were found are a molar of Burchell's zebra and a carpal bone (carpale magnum) of domestic cattle.

2.7.2. Benfica This site lies at the seashore about $17 \mathrm{~km}$ south of Luanda. It yielded some surface lithic material comparable to the Lupembo-Tshitolian complex of Central Africa, which was, however, never found in stratigraphical context. A thick layer of shells was found between $15 \mathrm{~cm}$ and $25 \mathrm{~cm}$ below the surface. It comprises mainly Anadara senilis, but also some Ostrea sp., Fucus sp., Murex sp. and Conus. This level has been excavated over a surface of $40 \mathrm{~m}^{2}$ (Dos Santos \& Ervedosa 1970) and yielded substantial quantities of pottery with a wide variety of incised decorations. Radiometric dates place the occupation for this shell midden between the second and fourth centuries AD (Lanfranchi \& Clist 1987). The fauna included numerous fish vertebrae, mammals and, possibly, also birds. No domestic animals are mentioned from this site. Among the mammal remains, J.W. Kitching identified a phalanx and an upper incisor of Burchell's zebra (Dos Santos \& Ervedosa 1970:49).

2.7.3. Cachama Cachama is a coastal site that lies close to Baïa Farta and has been excavated in different loci (Pinto 1988). Cachama 3, analyzed over a surface of $120 \mathrm{~m}^{2}$, yielded an undated Iron Age level. Cachama 1 was excavated over a surface of $165 \mathrm{~m}^{2}$ and yielded late Iron Age and Iron Age horizons. The upper horizon contained pottery and was rich in faunal remains but is thus far undated. The fauna comprises mainly marine fish, some mammal bone and few remains of birds. A preliminary analysis showed that no domestic animals were present (Van Neer, unpubl. data).

\section{Discussion and conclusions}

\subsection{Presence of the different domestic species}

The faunal record for Central Africa is very limited as a result of the poor preservation chances and the relatively low number of sites excavated in this vast region. The foregoing overview of sites with fauna, dating roughly to the last three millennia, shows the presence of some relatively early finds of domesticates on certain sites, whereas, at the same time, such animals are lacking on several settlements where their presence could not be excluded a priori on the basis of the archaeological context and the age of the site.

The keeping and propagation of domestic stock was certainly hampered by environmental factors, as it is today. Trypanosomiasis limits the distribution of zeboid cattle in humid and forested areas although certain breeds such as the Ndama and Muturu cattle have adapted to the tsetse challenge of this environment. Since the larger part of the area considered in this overview is forested, it is unsurprising that few indications for the presence of domestic cattle have been found. Archaeozoological evidence for the presence of cattle is available in the interlacustrine area at Tongo (Zaïre: third to sixth centuries AD), Remera I (third to fourth centuries AD), Kabuye XIV and Gisagara (Rwanda: eleventh to twelfth centuries AD), Akameru and Cyinkomane (Rwanda: ninth to thirteenth centuries $A D$ ), Ryamurari (Rwanda: seventeenth to twentieth centuries $\mathrm{AD}$ ) and at a mound on the Ruzizi plain (Burundi: seventeenth to twentieth centuries $A D$ ). The only other finds are from Kamabanga (ninth to tenth centuries AD) and Kitala (thirteenth to fourteenth centuries $A D$ ) in Angola and from Mashita Mbanza (sixteenth to twentieth centuries AD) in Zaïre. In all these areas cattle are also kept today. 
The sheep and goats that occur in forested areas of Africa today are dwarf breeds. Faunal remains from Nkang, where both dwarf sheep and goat were found, show that these adaptations go back in this region to at least the first millennium BC. Dwarf goat has also been found at Sanga (Zaïre: tenth to thirteenth centuries $\mathrm{AD}$ ) in a lakeside site; the goat and sheep from Tongo (third to sixth centuries AD) are also of rather small stature $(52 \mathrm{~cm}$ and $47 \mathrm{~cm}$ withers height, respectively). Evidence for small goats was also found at Mondongué (Central African Republic: sixteenth to twentieth centuries AD). Unidentified ovicaprines are present at Gisagara (Rwanda: eleventh to twelfth $\mathrm{AD}$ ), whereas both sheep and goat were found at Akameru and Cyinkomane (Rwanda: ninth to thirteenth centuries AD). No indications on the size of those ovicaprines is available, however.

Domestic chicken has been found at several second millennium AD sites of which the tenth to thirteenth century AD finds from a Kisalian grave in the Upemba region and the ninth to thirteenth century finds of Akameru and Cyinkomane (Rwanda) are the earliest. The eighteenth to nineteenth century levels of Kiantapo in Shaba, Zaïre yielded also chicken remains of a relatively small breed. None of the galliform bird remains found at the third to sixth centuries AD site of Tongo belong to domestic fowl.

Evidence for other domestic species is scanty. Domestic pig has only been found at the site of Nkile, dated to the seventeenth to nineteenth centuries AD. Given the relatively young age of this material it is likely that the pigs kept.at Nkile resembled those still found in the region, i.e. with slender legs and a long snout. Nkile and Lingbangbo (Central African Republic: fourteenth to seventeenth centuries AD) are the only Central African sites where the presence of domestic dog has been attested with certainty. It was impossible to decide whether the few canid remains from the Iron Age levels of Matupi belong to a jackal or to domestic dog.

\subsection{Origin and propagation of Central African domesticates}

The southward migration of pastoralists from the Sahara, roughly between $3000 \mathrm{BC}$ and $2000 \mathrm{BC}$, is well documented (Gautier 1987). Several sites illustrate the further southward propagation of ovicaprines and domestic cattle in the savanna belt. South of Lake Chad small and large livestock dated to the second half of the first millennium BC have been found at Maroua in northern Cameroon (Quéchon 1974) and at Daima in Nigeria, close to the Cameroonian border (Connah 1976, 1981). The more extensive and more securely dated material from Gajiganna, Nigeria is much older (Breunig 1995, Breunig et al. 1996). The oldest cattle, sheep and goat remains occur in levels dated between about $2300 \mathrm{BC}$ and $1900 \mathrm{BC}$.

Domestic stock has also been reported from Ntereso and Kintampo Rockshelter 6 in Ghana (Carter \& Flight 1972). The former site is located in dry savanna woodland, whereas the latter is situated at the fringe of the high forest. At Ntereso, dated between about $2100 \mathrm{BC}$ and $1300 \mathrm{BC}$, goat bones are rare and have been attributed to a dwarf breed. A bovine second phalanx is present as well but the authors hesitate in attributing it to domestic cattle. Kintampo Rockshelter 6 compares closely in date to Ntereso (Stahl 1985). The bovine remains found in a level dated between $2130 \mathrm{BC}$ and $1740 \mathrm{BC}$ were attributed to domestic cattle bv Carter \&
Flight (1972) on the basis of a comparative metrical analysis of modern cattle and African buffalo. These identifications have been questioned in the literature (Stahl 1985), but apparently the material has never been re-analyzed using the morphological criteria established by Peters (1988). Kintampo K6 also yielded bones of goat which were identified as a dwarf breed. The length of the mandibular row of a Kintampo specimen compares closely with measurements of dwarf goats from Malakal, Sudan (Carter \& Flight 1972). The values observed for this measurement in normal goats is, however, similar to those found in the Kintampo specimen (Gautier 1987), despite the fact that dwarf goats have a skull which is, in comparison to normal goats, reduced in length, width and height (Chang \& Landauer 1950). Given the location of Kintampo close to the rainforest, it is very likely that a dwarf breed of goat was indeed present, but a re-study of the material using other measurements and considering more modern material would be preferable to confirm this. The site of Nkang near Yaoundé, Cameroon, is located in a savanna-forest mosaic and yielded sheep and goat bones from a small breed. This shows that a process of dwarfing has gone along with the introduction of ovicaprines in the forested areas of Africa. No other west-central African sites are available to illustrate the further early spread of domestic animals to the south.

It has been suggested on the basis of linguistic evidence that demographic pressure forced Bantu-speaking populations to emigrate from their initial homeland in the Grassfields of Cameroon. These people, whose lifestyle was not adapted to the forest, would have migrated from west to east through the savanna to finally reach the interlacustrine region (Bastin et al. 1979, 1982, Meussen 1980). After a relatively long stay in this area, a farther southward and then westward migration would have brought them to the savanna south of the equatorial forest. Certain groups, however, would have been able to cross the rainforest belt by taking a more westerly route along the coastline or by travelling south along the waterways farther east (Bastin 1978, David 1980). Archaeological data to support these hypothetical itineraries are scanty (Maret 1986) but botanical evidence shows that, as a result of the last Holocene dry phase, savanna corridors existed in the forest (Schwartz et al. 1990, Roche 1991) which would have made it easier for Bantu populations to reach the southern savannas. In that area both the eastern and the western migratory waves would have met. Thus far no evidence is available for domestic animals in the sites of the Grassfields of Cameroon. The same is true for Oveng, which is the only early site with fauna in west-central Africa. People relied mainly on fishing and shell collecting. Mammals were heavily under-represented at this site which yielded pottery, iron slag, Elaeis and Coula. In the region just south of the Central African rainforest, sites with domesticates dating to the end of the first millennium $B C$ or the first half of the first millennium AD are also absent. The Ngovo Group in Lower Zaïre is the only known archaeological assemblage, dated shortly beforc our era and located at the southern edge of the forest, that comprises pottery and polished stone tools. It has been suggested that the Ngovo Group represents the first, or in any case very ancient, Bantu-speaking populations that would have crossed the rainforest and settled in the savannas to the south (de Maret 1986) nnly two cites of the Nonvo Gromn. Nenvo and Dimha. have vielded fauna. Both 
assemblages are small and lack domestic animals. Hence the archacozoologica data available thus far do not support the hypothesis that early Bantu-speaking populations were responsible for the propagation of food production. It is not clear to what extent the present faunal record can be generalized. It should be underlined that the assemblages from Ngovo and Dimba caves were small and that the excavated deposits may have been partly related to ritual practices. The cave sites of Cameroon lie in the Grassfields but their immediate surroundings were heavily wooded. Sites like Shum Laka may not represent living sites, but could instead have been places where hunters halted temporarily and where their dead were buried. Firm botanical evidence for food production is not available either. Methodological problems do not allow confirmation of the domestic status of the sporadic remains of Elaeis and Canarium (Eggert 1993).

The interlacustrine region probably played a more important role in the propagation of domestic animals. It is very suitable for herding (Epstein 1971i:410) as a result of the extensive grassland vegetation in highly elevated areas where tsetse fly and trypanosomiasis are lacking. It is not clear whether the first inhabitants of the interlacustrine region were Bantu-speaking populations coming from the west or if they were Nilotic pastoralists coming from the east, or a mixture of both populations. Both groups may have started their migrations towards this area during the second millennium BC. Palynological evidence shows that early Iron Age groups, belonging to the Urewe culture, had a profound impact on the environment, especially during the first centuries of our era. The cumulative effect of the overexploitation of the environment and a dry climatic phase negatively influenced human habitation in the area. Especially in Rwanda, this resulted in a reduction of the exploited territory during the first few centuries. This in turn allowed a regeneration of the environment. The following late Iron Age period was characterized by the use of new metallurgical techniques and of roulette-decorated pottery. From this period onwards the need for more pasture and new agricultural land increased pressure on the environment (Roche 1991).

It has been suggested in the literature that a small breed of zebu cattle was first introduced in the interlacustrine region during the first millennium $\mathrm{BC}$. A larger breed of humpless longhorn cattle would have been brought in during the late Iron Age by a new wave of Nilotic pastoralists coming from the east. The archaeozoological data to support this model are very scanty, however, and new evidence from Tongo seems to contradict it. The third to fourth centuries AD cattle finds from Remera I, Rwanda comprise only two teeth. On the basis of the length of the lower third molar it is supposed that a small breed of about $110 \mathrm{~cm}$ shoulder height was present (Van Grunderbeek et al. 1983). This could correspond to the small zebu cattle that was supposedly introduced from the northeast in the first millennium BC of which the present-day inkuku cattle, a small breed of shorthorn zebu, might be a descendant (Gotanègre et al. 1974, Roche 1991:201).

According to oral tradition, the large longhorn Batutsi cattle would have been introduced in the region later during the twelfth (Kagame 1972) or the fourteenth centuries AD (Vansina 1962). The seventeenth to twentieth century faunal material from Ryamurari comprises two almost complete skulls with the horn cores
Table 9.7 Contribution of hunting, fishing and stock herding at some Central African sites and al (jajiganna, Nigeria. The calculations were based on the relative abundance of the remains. Sample size indicates NISP. (* dog remains have not been included;

** dog remains have been included because cut marks were present.)

\begin{tabular}{lcccc}
\hline & sample size & fishing & hunting & herding \\
\hline Gajiganna A & 1610 & 24.2 & 7.4 & 68.4 \\
Gajiganna B & 1336 & 60.7 & 4.6 & 34.7 \\
Nkang & 40 & 7.5 & 80.0 & 12.5 \\
Lingbangbo \& Mondongué & 109 & 29.4 & 63.3 & $7.3^{*}$ \\
Mashita Mbanza & 14 & - & 78.6 & 21.4 \\
Nkile & 112 & 88.4 & 8.0 & $3.6^{* *}$ \\
Tongo late Iron Age & 75 & 28.0 & 25.4 & 44.6 \\
Tongo early Iron Age & 83 & 32.6 & 31.5 & 36.9 \\
Akameru & 51 & - & 64.7 & 35.3 \\
Cyinkomane & 118 & - & 44.1 & 55.9 \\
Ruzizi & 753 & 96.3 & 0.4 & 3.3 \\
\end{tabular}

preserved. They are very long and lyre-shaped and correspond well to the Batutsi longhorn (Tshilema Tshiluka 1983). Gautier (1983b) estimates the shoulder height of the Ryamurari cattle at $110-130 \mathrm{~cm}$, which would not exclude an attribution to the large breed. At the ninth to thirteenth centuries sites of Akameru and Cyinkomane, shoulder height was estimated at 105-130 cm (Gautier 1983a). A closer look at the available measurements and comparison with the material from Tongo shows, however, that the observed variation is not very large (Table 9.6). With the exception of a large second phalanx from the early Iron Age levels of Tongo, the measurements do not seem to exceed the expected variation in a single breed. The large size of a single early Iron Age second phalanx from Tongo, furthermore, contradicts the suggestion that only a small breed would have preceded the larger Batutsi type. Thus, the raw data are insufficient to draw any reasonable conclusions concerning the breeds of ancient cattle in the interlacustrine region.

\subsection{The importance of domestic animals in subsistence}

There seems to be considerable variation in the degree of reliance on livestock herding in Africa. Typical pastoralist communities relying almost exclusively on domestic stock have been described from several sites outside Central Africa. Examples are the 2600-1000 BC sites from Wadi Howar in Sudan (Van Neer \& Uerpmann 1989) and several Pastoral Neolithic sites in East Africa (Marshall \& Stewart 1994). Other sites such as Gogo Falls in Kenya (ibid.) and the Gajiganna series in Nigeria (Breunig et al. 1996) show that, in addition to keeping of domestic stock, hunting and fishing could also play a major role in the subsistence of pastoralists. Table 9.7 indicates the relative importance of hunting, fishing and herding, expressed as percentages of the number of identified specimens (NISP) of the different taxa for a number of sites. The data from Gogo Falls cannot be presented in the 
Table 9.8 Relative abundance of domestic and wild animals (excluding fish) of Central African sites compared to that of Gajiganna, Nigeria and Gogo Falls, Kenya. The sites have been arranged in descending order of the contribution of domestic animals.

\begin{tabular}{lccc}
\hline & sample size & hunting & herding \\
\hline Gajiganna A & 1221 & 9.8 & 90.2 \\
Ruzizi & 28 & 10.7 & 89.3 \\
Gajiganna B & 525 & 11.6 & 88.4 \\
Tongo late Iron Age & 54 & 35.2 & 64.8 \\
Tongo early Iron Age & 58 & 43.1 & 56.9 \\
Cyinkomane & 118 & 44.1 & 55.9 \\
Gogo Falls & 612 & 46.4 & 53.6 \\
Akameru & 51 & 64.7 & 35.3 \\
Nkile & 13 & 69.2 & 30.8 \\
Mashita Mbanza & 14 & 78.6 & 21.4 \\
Nkang & 37 & 86.5 & 13.5 \\
Lingbangbo \& Mondongué & 77 & 89.6 & 10.4 \\
\hline
\end{tabular}

same way since the analysis of the mammal fauna considered only teeth, thereby differing from the approach at the other sites where all the mammal remains were included. The importance of hunting versus stock herding has been presented in Table 9.8 by omitting the fish remains. This also allows the inclusion of the data from Gogo Falls if we assume that the ratio given by the dental remains is comparable to the one that would be obtained if post-cranial remains were also included. The ratio of domestic versus wild animals (excluding fish) is about 9:1 at Gajiganna and at the mound in the Ruzizi plain. In the interlacustrine region, Ryamurari, Gisagara, Kabuye and Remera have also yielded a fauna dominated by domestic stock, although it should be emphasized that the available samples are small. More extensive faunal assemblages will be needed in order to confirm that specialized, livestock-oriented groups occurred since the early Iron Age.

Other sites from the interlacustrine region (Tongo, Cyinkomane and Akameru) have higher proportions of wild animals. Their contribution is comparable to that seen at Gogo Falls. The relatively high proportion of wild animals at Gogo Falls is seen as a possible result of environmental constraints (Marshall \& Stewart 1994) Drought and disease on that site may have resulted in a diversification of subsistence strategies. The palaeoenvironmental reconstruction based on the wild fauna indicates a mosaic habitat including grassland, bush and woodland in which tsetse fly and trypanosomiasis probably occurred. The faunas from Tongo, Cyinkomane and Akameru comprise substantial numbers of remains from woodland species indicating that at the time of the considered Iron Age occupation the environment was more forested than today. As a result of the high elevation, between $1700 \mathrm{~m}$ and $1800 \mathrm{~m}$ a.s.l., the environment of both sites in Rwanda was free of trypanosomiasis. The surroundings of Tongo lie at an altitude between $1400 \mathrm{~m}$ and $1500 \mathrm{~m}$ and are suitable for herding as well. Cyinkomane and Akameru being cave sites, it 
had been suggested by Gautier (1983a) that the high ratio of wild animals, and also the observed variation in their contribution, could be related to the function of the caves as refuge places during times of instability. Since Tongo is an open air site the frequent occurrence of wild animals cannot be explained as a result of troubles in the area due to migrations or other political factors. Moreover, it is striking that at Tongo the ratio of wild animals is equally high during both early and late Iron Age. A mixed economy of herding and hunting may have been a deliberate choice in this area, differing from the present-day lifestyle of stock-oriented pastoralists, agricultural groups or hunter-gatherer societies.

South of the equatorial forest, at Mashita Mbanza, the contribution of domestic stock (ovicaprines and cattle) is low despite the location of the site in an open environment suitable for herding. It is not clear whether this is an artefact related to the low number of identifiable remains collected at that site. The remaining sites, Nkile, Nkang, Lingbangbo and Mondongué, are located in the rainforest or in forest-savanna mosaic and yielded low numbers of domestic animals (mainly dwarf ovicaprines). Although these data should be used with caution because of the small sample sizes, it seems that the keeping of large herds of domestic stock was never practised, possibly because the demographic pressure in these areas was not so high as in savanna environment.

\section{Note}

1. This text presents research results of the Belgian programme on Inter-University Poles of Attraction initiated by the Belgian State, Prime Minister's Office, Federal Services. I also thank Prof Achilles Gautier (University of Ghent) for putting at my disposal the unpublished faunal data from some sites in Rwanda. Mr Alain Reygel (Tervuren) prepared the drawing for this paper.

\section{References}

Asombang, R. 1988. Bamenda in prehistory: the evidence from Fiye Nkwi, Mbi crater and Shum Laka rockshelters. $\mathrm{PhD}$ thesis, Institute of Archaeology, University of London.

Asombang, R. \& P. de Maret 1992. Re-investigating Shum Laka: the December 1991-March 1992 campaign. Nsi 10/11, 13-16.

Bastin, Y. 1978. Statistique grammaticale et classification des langues bantoues. Linguistics in Belgium 2, 17-37.

Bastin, Y., A. Coupez, B. de Halleux 1979. Statistique lexicale et grammaticale pour la classification des langues bantoues. Bulletin de l'Académie royale des Sciences d'Outre-Mer 3, 375-87.

Bastin, Y., A. Coupez, B. de Halleux 1982. Classification lexicostatistique des langues bantoues (214 relevés). Bulletin de l'Académie royale des Sciences d'Outre-Mer 27(2), 173-99.

Breuil, H. 1952. Les figures incisées et ponctuées de la grotte de Kiantapo (Katanga). Annales du Musée du Congo Belge, sér. in $8^{\circ}$. Sciences de l'Homme. Préhistoire 1, 1-33.

Breunig, P. 1995. Gajiganna und Koduga. Zur frühen Besiedlung des Tschadbeckens in Nigeria. Beiträge zur Allgemeinen und Vergleichenden Archäologie 15, 3-48.

Breunig, P., K. Neumann, W. Van Neer 1996. New research on the holocene settlement and environment of the Chad Basin in Nigeria. The African Archaeological Review 13, 111-45.

Brooks, A.S. \& C.C. Smith 1987. Ishango revisited: new age determinations and cultural interpretations. African Archaeological Review 5, 65-78. 
Brooks, A.S., D.M. Helgren, J.S. Cramer, A. Franklin, W. Hornyak, J.M. Keating, R.G. Klein, W.J. Rink, H. Schwarcz, J.N.L. Smith, K. Stewart, N.E. Todd, J. Vernicrs, J.E. Yellen 1995. Dating and context of three Middle Stone $\Lambda g e$ sites with bone points in the Upper Semliki Valley, Zilire. Secience $268,548-53$

Cabu, F. 1938. Premières notes d'ensemble de la mission de recherches préhistoriques au Katanga (Congo Belge). Bulletin de la Société Préhistorique Française 25, 172-86.

Carter, P.L. \& C. Flight 1972. A report on the fauna from the sitcs of Ntereso and Kintampo Rock Shelter 6 in Ghana: with evidence for the practice of animal husbandry during the second millennium B.C. Man 7, 277-82.

Chang, T.K. \& W. Landauer 1950. Observations on the skeleton of African dwarf goats. Journal of Morphology 86, 367-76.

Claes, P. 1985. Contribution à l'étude de céramiques anciennes des environs de Yaoundé. Mémoire de licence, Université Libre de Bruxelles.

Clist, B. 1987. Early Bantu settlements in west Central Africa: a review of recent research. Current Anthropology 28, 380-82.

Clist, B. 1989. La campagne de fouilles 1989 du site Age du Fer ancien d'Oveng: province de l'Estuaire (Gabon). Nsi 5, 15-18.

Connah, G. 1976. The Daima sequence and the prehistoric chronology of the Lake Chad region of Nigeria. Journal of African History 17, 321-52.

Connah, G. 1981. Man and a lake. In Le Sol, la Parole et l'Ecrit. Mélanges en Hommage à Mauny. Société Française d'Histoire d'Outre-Mer (ed.), 161-78. Paris: Socićté Française d'Histoire d'Outre-Mcr.

Cooke, H.B.S. \& A.F. Wilkinson 1978. Suidae and Tayassuidac. In Evolution of African manmmals, V.J. Maglio \& H.B.S. Cooke (eds), 435-82. Cambridge, Mass.: Harvard University Press.

Cornelissen, E., J. Moeyersons, P. de Maret 1995. Fouilles archéologiques à Shum Laka (Cameroun). Nouvelles de la Science et des Technologies 13, 319-22.

David, N. 1980. Early Bantu expansion in the context of Central African prehistory: 4000-1 BC. Colloque du C.N.R.S. L'expansion bantoue, n.s. 2: 265-78.

de Heinzelin de Braucourt, J. 1957. Les fossiles d'Ishango. Exploration du Parc National Albert, 20 série, fasc. 1. Brussels: Institut des Parcs Nationaux du Congo Belge.

de Maret, P. 1980. Preliminary report on 1980 fieldwork in the Grassfields and Yaounde, Cameroon. Nyame Akuma 17, 10-12.

de Maret, P. 1982. New survey of archaeological research and dates for West Central and North Central Africa. Journal of African History 23, 1-15.

de Maret, P. 1985a. Fouilles archéologiques dans la vallée du Haut-Lualaba, Zaïrc. II, Sanga et Katongo, 1974. Annaless du Muscée Royal de l'Afritue Centrale, Sciences Humaines No. 120. Tervuren: Musćc Royal de l'Afrique Centrale.

de Maret, P. 1985b. Recent archacological research and dates from Central Africa. Journal of African History 26, 129-48.

de Maret, P. 1986. The Ngovo Group: an industry with polished stone tools and pottery in Lower Zaire. African Archaeological Review 4, 103-33.

de Maret, P. 1991. La recherche archéologique au Cameroun. In Actes de la Journée d'Etude "La Recherche en Sciences humaines au Cameroun" (Bruxelles, 20 juin 1989), P. Salmon \& J.-J. Symoen (eds), 37-51. Brussels: Académie Royale des Sciences d'Outre-Mer.

de Maret, P., B. Clist, W. Van Neer 1987. Résultats des premières fouilles dans les abris sous roche de Shum Laka et Abcke au nord-ouest du Cameroun. L'Anthropologie 91, 559-84.

de Maret, P., R. Asombang, E. Cornelissen, P. Lavachery, J. Moeyersons, W. Van Neer 1993. Preliminary results of the 1991-1992 field season at Shum Laka, Northwestern Province, Cameroon. Nyame Akuma 39, 13-15

de Maret, P., R. Asombang, E. Cornelissen, P. Lavachery, J. Moeyersons 1995. Continuing research at Shum Laka rock shelter, Cameroun (1993-1994 field season). Nyame Akuma 43, 2-3.

De Meulemeester, J. \& A. Waleffe 1973. Résultats des travaux de fouilles dans une butte de la plaine de la Ruzizi (Burundi). Africa-Tervuren 19, 16-24.

Deschamps, R. 1986. Remains of flora. African Archaeological Review 4, 113 only.

Dos Santos Jnr, R. \& C. Ervedosa 1970. A estaçao arqueologica de Benfica. Ciencias Biologicas (Luanda) 1, 33-51.
Eggert, M.K.H. 1983. Remarks on exploring archacologically unknown rain forest territory: the case of Central Africa. Beilräge zur Allgemeine'n und Vergleichenden Archäologie' 5, 283-322.

liggert, M.K.H. 1984. Imbonga und Lingonda: zur frühesten Besiedlung des zentralafrikanischen Regenwaldes. Beiträge zur Allgemeinen und Vergleichenden Archäologie 6, 247-88.

Eggert, M.K.H. 1987. Imbonga and Batalimo: ceramic evidence for early settlement of the equatorial rainforest. African Archaeological Review 5, 129-45.

Eggert, M.K.H. 1993. Central Africa and the archacology of the equatorial rainforest: reflections on some major topics. In The archaeology of Africa. Food. metals and towns, T. Shaw, P. Sinclair B. Andah, A. Okpoko (eds), 289-329. London: Routledge.

Epstein, H. 1971. The origin of the domestic animals of Africa [2 volumes]. New York: Africana Publishing.

Flannery, K.V. 1972. The cultural evolution of civilizations. Annual Review of Ecology and Systematic 3, 399-426.

Gautier, A. 1983a. Les restes osseux des sites d'Akameru et de Cyinkomane (Ruhengeri, Rwanda). In L'histoire archéologique du Rwanda, F. Van Noten (ed.), Annales du Musée Royal de l'Afrique Centrale, Sciences Humaines No. 112, 104-20. Tervuren: Musée Royal de l'Afrique Centrale.

Gautier, A. 1983b. Les restes de mammifères du gisement protohistorique Hima à Ryamurare (Rwanda 17e-18e siècle). In L'histoire archéologique du Rwanda, F. Van Noten (ed.), Annales du Musée Royal de l'Afrique Centrale, Sciences Humaines No. 112, 121-6. Tervuren: Musée Royal de l'Afrique Centrale.

Gauticr, A. 1987. Prchistoric men and cattle in North Africa: a dearth of data and a surfeit of models. In Prehistory of arid North Africa, A.E. Close (ed.), 163-87. Dallas: Smu Press.

Gautier, A. n.d. Les restes de mammifères de Gisagara près de Butare. Unpublished report.

Geyh, M.A. \& P. de Maret 1982. Histogram evaluation of ${ }^{14} \mathrm{C}$ dates applied to the first complete Iron Age sequence from West Central Africa. Archaeometry 24, 158-63.

Gotanègre, J.F., C. Prioul, P. Sirven 1974. Géographie du Rwanda. Brussels: De Boeck.

Hopwood, A.T. \& X. Misonne 1959. Mammiferes fossiles. Exploration du Parc National Albert. Mission de Heinzelin de Braucourt, 1950, fasc. 4, 111-19. Brussels: Institut des Parcs Nationaux du Congo Belge.

Kagame, A. 1972. Un abrégé de l'ethno-histoire du Rwanda. Université nationale du Rwanda, collection Muntu, 3(1)

Kanimba, M. \& S. Gatare 1992. Archaeological and ethnoarchaeological research in the zones of Rutshuru and Masisi in Northern Kivu. Nyame Akuma 38, 66-71.

Koté, L. 1992. Naissance et développement des économies de production en Afrique centrale. Unpublished Doctoral thesis, Paris X.

Lanfranchi, R. \& B. Clist 1987. Mission de recherches et de formation en R.P. d'Angola, October 1987. Nsi 2, 4-8.

Maes, J. 1935. Le camp de Mashita Mbansa et les migrations des Bapende. Congo 2(5), 713-24.

Maquet, E. \& J. Hiernaux 1969. Un site à poterie cannelée en République Démocratique du Congo: Kawezi (vallée de la Ruzizi). Journal de la Société des Africanistes 39, 159-71.

Marshall, F. \& K. Stewart 1994. Hunting, fishing and herding pastoralists of western Kenya: the fauna from Gogo Falls. Archaeozoologia 7, 7-27.

Mbida, M.C. 1996. L'émergence de communautés villageoises au Cameroun méridional. Etude archéologique des sites de Nkang et de Ndindam. Doctoral thesis, Université Libre de Bruxelles.

Meussen, A. 1980. Apports nouveaux en matière de classification et du degré d'archaïsme des langues

bantoues. Colloque du C.N.R.S. L'expansion bantoue, n.s. 2, 457-72.

Mortelmans, G. 1952. Les dessins rupestres gravés, ponctués et peints du Katanga. Essai de synthèse. Annales du Musée du Congo Belge, sér. in 80, Sciences de l'Homme. Préhistoire 1, 33-55.

Mortelmans, G. \& P. de Maret 1989. Résultats des fouilles de 1955 devant la grotte de Kiantapo au Shaba. In Contribution to the archaeozoology of Central Africa, W. Van Neer (ed.), Annales du Musée Royal de l'Afrique Centrale, Sciences Zoologiques No. 259, 137-40. Tervuren: Musée Royal de l'Afrique Centrale.

Peters, J. 1988. Osteomorphological features of the appendicular skeleton of African buffalo, Syncerus caffer (Sparrman 1779) and of domestic cattle, Bos primigenius f. taurus Bojanus, 1827. Zeitschrift 
Peters, J. 1990. Late Pleistocene hunter-gatherers at Ishango (eastern Zä̈re): the faunal evidence. Revule de Paléobiologie 9, 73-112.

Pierot, F. 1987. Etude ethnoarchéologique du site de Mashita Mbanza (Zaïre). Mémoire de liennce, Université Libre de Bruxelles.

Pinto, L.P. 1988. Le Musée National d'Archéologie de Benguela (Angola): bilan des premiers travaux: 1979-1987. Nsi 3, 5-14

Quéchon, G. 1974. Un site protohistorique de Maroua (Nord-Cameroun). Cahiers de Sciences Humaines, ORSTOM 11, 3-46.

Roche, E. 1991. Evolution des paléoenvironnements en Afrique ecntrale et orientale au Pléistocène supéricur et à l'Holocène. Influences climatiques et anthropiques. Bullesin de la Société géographique de Liège 27, 187-208.

Schwartz, D., H. de Foresta, R. Deschamps, R. Lanfranchi 1990. Découverte d'un premier site de l'Age du Fer ancien (2.110 B.P.) dans le Mayumbe congolais. Implications paléobotaniques et pédologiques. Comptes Rendus hebdomadaires des Séances de l'Académie des Sciences Paris 310(2), 1293-8.

Stahl, A.B. 1985. Reinvestigation of Kintampo 6 rock shelter, Ghana: implications for the nature of culture change. The African Archaeological Review 3, 117-50.

Tchernov, E. 1993. The impact of sedentism on animal exploitation in the southern Levant. In Archaeozoology of the Near Eust. Proceedings of the first international symposium on the archaeozoology of southwestern Asia and adjacent areas, H. Buitenhuis \& A.T. Clason (eds), 10-26. Leiden: Universal Book Services.

Tshilema Tshiluka 1983. Ryamurare, capitale de l'ancien Royaume du Ndorwa. In L'histoire archéologique du Rwanda, F. Van Noten (ed.), Annales du Musée Royral de l'Afrique Centrale. Sciences Humaines No. 112, 149-53. Tervuren: Musée Royal de l'Afrique Centrale.

Van Grunderbeek, M.C., E. Roche, H. Doutrelepont 1982. L'âge du fer ancien au Rwanda et au Burundi. Archéologie et environnement. Journal de la Société des Africanistes 52, 5-88.

Van Grunderbeek, M.C., E. Roche, H. Doutrelepont 1983. Le premier Age du Fer au Rwanda et au Burundi. Archéologie et environnement. Institut National de Recherche Scientifique, Publication 23. Butare: Institut National de Recherche Scientificue.

Van Neer, W. 1986. Faunal remains. African Archaeological Review 4, 109 and 113.

Van Neer, W. 1989. Contribution to the archacozoology of Central A frica. Annales du Musée Royal de l'Afrique Centrale, Sciences Zoologiques 259. Tervuren: Musée Royal de l'Afrique Centrale.

Van Neer, W. 1990. Les faunes de vertébrés quaternaires en Afrique centrale. In Paysages quaternaires de l'Afrique centrale atlantique, R. Lanfranchi \& D. Schwartz (eds), 195-220. Paris: ORSTOM.

Van Neer, W. \& B. Clist 1991. Le site de l'Age du fer Ancien d'Oveng (Province de l'Estuaire, Gabon), analyse de sa faune et de son importance pour la problématique de l'expansion des locuteurs bantu en Afrique Centralc. Comptes Rendus hebdomadaires des Séances de l'Académie des Sciences Paris 312(II), $105-10$.

Van Neer, W. \& H.-P. Uerpmann 1989. Palacoecological significance of the Holocene faunal remains of the B.O.S.-missions. In Forschungen zur Umweltgeschichte der Ostsahara, R. Kuper (ed.), Africa Praehistorica 2, 307-4l.

Van Noten, F. 1977. Excavations at Matupi cave Antiguity 51, 35-40.

Van Noten, F. (ed.) 1983. Histoire archéologique du Rwanda. Annales du Musée Royal de l'Afrique Centrale, Sciences Humaines No. 112. Tervuren: Musée Royal de l'Afrique Centrale.

Vansina, J. 1962. L'évolution du rovaume Rwanda des origines à 1900. Mémoire de l'Académie royale des Sciences d'Outre-Mer, Classe des Sciences morales et politiques, 26(2). Brussels: Acadćmic Royale des Sciences d'Outre-Mer.

von den Driesch, A. 1976. A guide to the measurement of animal bones from archaeological sites. Peabody Museum Bulletin 1. Cambridge, Mass.: Pcabody Museum.

von den Driesch, A. \& J. Boessneck 1974. Kritische Anmerkungen zur Widerristhöhenberechnnung aus Längenmassen vor- und frühgeschichtlicher Tierknochen. Säugetierkundliche Mitteilungen 22, 32548.

Warnier, J.P. \& R. Asombang 1982. Archaeological research in the Bamenda Grassfield, Cameroun.

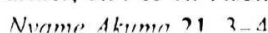

